\title{
The uncertainty of results when estimating daily milk records
}

\author{
Marjeta ČANDEK-PotoKAR*, Maja PREVOLNIK, Drago BABNIK, \\ TOMaž PERPAR
}

Agricultural Institute of Slovenia, Hacquetova 17, 1000 Ljubljana, Slovenia

(Received 26 January 2006 - Accepted 16 September 2006)

\begin{abstract}
Two studies were conducted to evaluate the uncertainty of measurements (daily milk yield, fat, protein and lactose content) on Slovenian milk recording data, respecting the ISO 5725 definition of precision i.e. as repeatability $\left(\mathrm{s}_{\mathrm{r}}\right)$ and reproducibility $\left(\mathrm{s}_{\mathrm{R}}\right)$ standard deviation. The aim of study 1 was to evaluate the within operator (repeatability) variability of daily measurements and to compare the precision of AT (alternating morning and evening milking records at subsequent monthly visits) and the ICAR standard reference A4 recording scheme (monthly records of two daily milkings). In study 2 we were interested in the reproducibility of milk recording results and the contribution of factors associated with the operator (official representative of the recording organization) and herd or residual variation. In addition, the precision of daily milk yield measurements was studied in relation to herd size and cow productivity. Study 1 was conducted on 332 cows from 14 herds with 14 operators. Study 2 was made on 57639 records gathered from the Slovenian central milk recording database. The results on two consecutive days were obtained by the same operator (study 1) or by operator and supervisor (study 2). Statistical analysis was performed on the differences between two consecutive days. The lower $\mathrm{s}_{\mathrm{r}}$ obtained for the AT than A4 recording method $(1.7 \mathrm{~kg}$ vs. $1.2 \mathrm{~kg}$, respectively) indicates a loss of precision in daily milk recording results due to the passage to the AT recording scheme. In current Slovenian situation (AT recording scheme), the reproducibility standard deviation obtained on two consecutive days was about $1.7 \mathrm{~kg}, 0.40,0.11$ and 0.09 for milk yield, fat, protein and lactose percentage indicating that we can normally expect the difference between regular control and supervision up to approximately $5 \mathrm{~kg}, 1.2 \%, 0.3 \%$ and $0.3 \%$ for daily milk yield, fat, protein and lactose, respectively. Similar estimates were obtained for repeatability and reproducibility standard deviation. Uncertainty in milk yield results explained by the factors related to the operator pair was minor $(0.4-2.5 \%)$ compared to herd related factors (11.0-15.1\%), while the main part (82.4-88.6\%) was due to biological variability and other uncontrolled factors. Lower reproducibility of daily milk yield was associated with small herds and/or lower productivity.
\end{abstract}

milk recording results / precision / repeatability / reproducibility

\footnotetext{
* Corresponding author: meta.candek-potokar@kis.si
} 
Résumé - Estimation de l'incertitude des résultats de performances dans le contrôle laitier. Deux études ont été menées pour évaluer l'exactitude des mesures (production laitière quotidienne, taux butyreux, taux protéique et teneur en lactose) sur les données du contrôle laitier en Slovénie, respectant la norme ISO 5725, i.e. exprimée par l'écart type de répétabilité $\left(\mathrm{s}_{\mathrm{r}}\right)$ et de reproductibilité $\left(\mathrm{s}_{\mathrm{R}}\right)$. Le but de l'étude 1 était d'estimer la répétabilité des mesures et de comparer la précision de la méthode de référence ICAR A4 (enregistrement mensuel des données sur les deux traites quotidiennes) à celle de la méthode AT (enregistrement mensuel des données sur une des deux traites, en alternance (matin et soir)). Dans l'étude 2, nous nous sommes intéressés à la reproductibilité des résultats et à l'importance des facteurs liés à l'opérateur (représentant officiel de l'organisation d'enregistrement) et au troupeau ou à la variabilité résiduelle. De plus, la précision de la mesure de la production laitière quotidienne a été étudiée par rapport à la taille du troupeau et à la productivité de la vache. L'étude 1 a été menée sur 332 vaches issues de 14 troupeaux avec 14 opérateurs. L'étude 2 a été effectuée sur 57679 enregistrements recueillis à partir de la base de données centrale slovène du contrôle laitier. Les résultats sur deux jours consécutifs ont été obtenus soit par le même opérateur (étude 1) soit par un opérateur et un contrôleur (étude 2). L'analyse statistique a été effectuée sur les différences entre les deux jours consécutifs. L'écart type de répétabilité a été supérieur avec la méthode AT comparativement à la méthode $\mathrm{A} 4(1,7 \mathrm{~kg}$ contre $1,2 \mathrm{~kg}$, respectivement), ce qui indique une perte de précision des résultats due à l'utilisation de la méthode AT. En Slovénie, dans la situation actuelle (méthode AT), l'écart type de reproductibilité obtenu sur deux jours consécutifs était d'environ $1,7 \mathrm{~kg}, 0,40 \%, 0,11 \%$ et $0,09 \%$ pour la production laitière quotidienne, le taux butyreux, le taux protéique et la teneur en lactose, respectivement. Ceci indique qu'une différence entre les résultats du contrôle par l'opérateur par rapport à celui du contrôleur peuvent normalement atteindre jusqu'à $5 \mathrm{~kg}, 1,2 \%, 0,3 \%$ et $0,3 \%$ pour la production laitière quotidienne, le taux butyreux, le taux protéique et la teneur en lactose, respectivement. Des valeurs très similaires ont été obtenues pour l'écart type de répétabilité et de reproductibilité. La variabilité expliquée par les facteurs liés à l'opérateur $(0,4-2,5 \%)$ était faible comparée aux facteurs liés au troupeau $(11,0$ $15,1 \%)$, la majeure partie $(82,4-88,6 \%)$ était due à la variabilité biologique et à d'autres facteurs non contrôlés. Une reproductibilité inférieure de la production laitière quotidienne a été associée aux petits troupeaux et/ou à une faible productivité.

contrôle laitier / précision / répétabilité / reproductibilité

\section{INTRODUCTION}

The milk recording system is a key source of information for breeding purposes (genetic improvement) and herd management (feeding decisions, health) in dairy cattle, and for that reason the accuracy of milk recording results is of great importance. The problem of accuracy in milk recording is related to the daily variation in milk yield and composition, which has been reported to be about $6-8 \%$ for milk yield, $5-8 \%$ for fat content, $1-2 \%$ for protein content and $1 \%$ for lactose content $[1,2,4,14,16,18,20]$. This variation is caused by different factors such as milking interval, milking frequency, udder emptying, sampling procedure, equipment, feeding regime, parity, and stage of lactation $[3,11,12,16,20]$. It is difficult to control all these factors, to equalize all conditions for milk recording performance and to avoid coincidental factors like heats, diseases, technical disruptions and others. However, on the long-term, factors that are randomly distributed are counterbalanced. Thus for breeding purposes the problems related to day to day variation are less critical, as the estimates of standard lactation yield are based on several recordings over the lactation period. On the contrary, the precision of daily results (measurements) in milk recording can be very important when we want to use the results for herd management or supervision in milk recording. The Slovenian milk recording organization obtained the official ICAR dry seal in 1996. The supervision of milk recording is practiced according to ICAR guidelines [6] in $10 \%$ of herds every year. Recently, the 
AT recording scheme (alternating morning and evening milking records at subsequent monthly visits) was adopted in Slovenia instead of the ICAR standard reference recording scheme A4 (monthly records of two daily milkings) and an increased incidence of deviations between regular and supervision records exceeding $\pm 10 \%$ tolerance was noted. The lack of information concerning the uncertainty of daily milk recording in relation to the recording method and operator taking measurement were the main motives for the study. The International Organization for Standardization has established general principles and definitions for estimating the accuracy (trueness and precision) of methods and results [7] and we have decided to respect these definitions. Such an approach in estimating the precision of measurements has already been undertaken in pig carcass classification [15] and corresponded to our goal i.e. estimating what difference between results on two consecutive days could be expected in case of the same operator (repeatability) and/or in case of different operators (reproducibility). Besides, we were interested in evaluating the contribution of factors associated with the operator and herd, as well as the precision of daily milk yield measurement in relation to herd size and/or cow productivity.

\section{MATERIALS AND METHODS}

\subsection{Definitions}

According to the ISO 5725 standard [7], the term accuracy involves trueness and precision and is described as the closeness of the agreement between a test result and the accepted reference value and involves a combination of random components and a common systematic error or bias component. The true value (and thus trueness) was, in our case, neither known nor of our interest. We focused on the precision i.e. the closeness of the agreement between independent test results obtained under stipulated conditions. It is expressed in terms of imprecision and computed as standard deviation of test results i.e. less precision is reflected by larger standard deviation. Repeatability is defined as precision under repeatability conditions (same method, identical items, same operator, same equipment and short interval of time) while reproducibility as precision under reproducibility conditions (same method, identical items, different operator, different equipment). Using the difference between results obtained on two consecutive days implies that the problem of not knowing the true value can be ignored and the bias of the measurement method will have no influence and can be ignored [7], but as a consequence the standard deviation of difference obtained has to be divided by $\sqrt{ } 2$ [7].

\subsection{Study 1 (Repeatability study)}

Data were collected in a trial carried out from May until October 2005 on 332 cows from 14 herds (farms) of different regions of Slovenia with 14 operators (official representatives of the recording organisation) participating. The cows were of different breeds (Black \& White, Brown, Simmental, Red Holstein breed and different crossbreeds), parities (1-14), and lactation stages. The number of cows per herd varied from 6 to 47. Operators participating in the study performed the measurements and samplings separately for morning (AM) and evening (PM) milkings on two consecutive days. Milk samples were analyzed for fat, protein, and lactose content by local laboratories of milk recording service using the mid infrared method (according to the laboratory, different types of apparatuses Milkoscan, Foss Electric, Hillerød, Denmark, were used). Daily results (milk yield and composition) were recorded according to A4 (monthly records of two 
daily milkings) and AT method (alternating morning and evening milking records at subsequent monthly visits) [6]. In case of A4 method, daily milk yield was determined as the sum of AM and PM milking, and daily milk composition as the weighed average of AM and PM milking. In case of AT recording method, daily milk yield and composition, except the lactose percentage (no adjusting), were calculated on the basis of one milking adjusted for milking interval and time of milking, using appropriate correction factors [9]. In case of AT method, daily results were calculated twice, on the basis of AM records, and on the basis of PM records.

Statistical analysis was carried out using SAS [17]. Means and standard deviations (PROC MEANS) were calculated for single milkings (AM and PM) and daily results. The VARCOMP procedure with the operator as the random effect was performed on the differences between repeated measurements on two consecutive days. The repeatability standard deviation $\left(\mathrm{s}_{\mathrm{r}}\right)$ was calculated as the square root of residual variance divided by 2 [7]. The repeatability limit (r) was calculated as $\sqrt{ } 2 \times 1.96 \times \mathrm{s}_{\mathrm{r}}$ or $2.8 \times \mathrm{s}_{\mathrm{r}}$ [7], denoting the value below which the absolute difference between two test results may be expected to lie (with a probability of $95 \%$ ).

\subsection{Study 2 (Reproducibility study)}

Data of regular and supervision control were collected from the Slovenian central milk recording database located at the Agricultural Institute of Slovenia. The records from the central milk recording database within a period from March 2004 until November 2005 were included in the data set of the second study. The records were collected according to the AT (alternating morning and evening milking records at subsequent monthly visits) method [6] in case of regular control, while in case of supervision control, the records were collected for AM and PM milkings. Only records that satisfied the following criteria were included: at least five cows per herd, at least five herds per pair of operators (operator $\times$ supervisor). Both the operator performing regular and the supervisor performing supervisory control were the official representatives of the recording organization. The records of milk yield and samples for milk composition (fat, protein, lactose content) were taken by two different operators within two consecutive days (regular control - day 1 and supervision control - day 2) as outlined in the ICAR guidelines [6]. The final data set for statistical analysis comprised 57639 records from 3241 herds (farms) recorded by 216 pairs of operators. The results are presented for AM and PM milkings and two daily computation methods: firstly according to the AT method (alternating morning and evening milking records at subsequent monthly visits) [6] for day 1 and day 2 , and secondly according to the AT method for day 1 and according to the A4 method for day 2.

Statistical analysis was carried out using SAS [17]. Means and standard deviations (PROC MEANS) were calculated for single milking (AM and PM) and daily results. We used the VARCOMP procedure [17] with the operator pair and herd nested within the operator pair as random effects to analyze the contribution of factors related to the operator, herd or residual. This analysis was made on differences between measurements on two consecutive days. The reproducibility standard deviation $\left(\mathrm{S}_{\mathrm{R}}\right)$ was calculated as the square root of the overall variance divided by 2 [7]. The reproducibility limit $(\mathrm{R})$ was calculated as $\sqrt{ } 2 \times 1.96 \times \mathrm{s}_{\mathrm{R}}$ or $2.8 \times \mathrm{s}_{\mathrm{R}}$ [7] denoting the value below which the absolute difference between two test results may be expected to lie (with a probability of 95\%). In addition, the reproducibility of milk yield was assessed according to herd 
Table I. Descriptive statistics (means \pm standard deviations) for milk yield and composition for the data of the repeatability study.

\begin{tabular}{lcccc}
\hline $\mathrm{n}=332$ & Milk $(\mathrm{kg})$ & Fat $(\%)$ & Protein $(\%)$ & ${\text { Lactose }(\%)^{1}}^{1}$ \\
\hline AM milking & & & \\
Day 1 & $9.3 \pm 3.6$ & $4.18 \pm 0.88$ & $3.48 \pm 0.36$ & $4.57 \pm 0.27$ \\
Day 2 & $9.5 \pm 3.6$ & $4.20 \pm 0.84$ & $3.47 \pm 0.38$ & $4.56 \pm 0.27$ \\
PM milking & & & \\
Day 1 & $9.4 \pm 3.6$ & $4.18 \pm 0.91$ & $3.46 \pm 0.38$ & $4.53 \pm 0.29$ \\
Day 2 & $9.4 \pm 3.6$ & $4.22 \pm 0.88$ & $3.47 \pm 0.38$ & $4.56 \pm 0.26$ \\
Daily results by A4 method & & & \\
Day 1 & $18.7 \pm 7.0$ & $4.18 \pm 0.79$ & $3.47 \pm 0.35$ & $4.55 \pm 0.26$ \\
Day 2 & $19.0 \pm 7.1$ & $4.21 \pm 0.77$ & $3.47 \pm 0.37$ & $4.56 \pm 0.26$ \\
Daily results by AT method on the basis of AM milking & & \\
Day 1 & $18.8 \pm 7.0$ & $4.12 \pm 0.72$ & $3.45 \pm 0.35$ & $4.57 \pm 0.27$ \\
Day 2 & $18.9 \pm 7.0$ & $4.17 \pm 0.67$ & $3.45 \pm 0.37$ & $4.56 \pm 0.27$ \\
Daily results by AT method on the basis of PM milking & & \\
Day 1 & $18.7 \pm 6.8$ & $4.20 \pm 0.71$ & $3.41 \pm 0.37$ & $4.53 \pm 0.29$ \\
Day 2 & $19.0 \pm 6.9$ & $4.23 \pm 0.70$ & $3.42 \pm 0.37$ & $4.56 \pm 0.26$ \\
\hline
\end{tabular}

${ }^{1}$ No correction of results in the AT method for lactose.

AM: morning.

PM: evening.

AT: monthly alternating recording method based on one daily milking adjusted for the interval between milkings and time of milking.

A4: monthly recording method based on two daily milkings.

size and cow productivity. In this case, reproducibility in relation to milk yield i.e. reproducibility relative to standard deviation $\left(\mathrm{RSD}_{\mathrm{R}}\right)$, was also determined [7]. On the basis of the reproducibility standard deviation $\left(s_{R}\right)$ and the acceptable deviation (AD) between regular and supervision control $( \pm 10 \%)$, we estimated the percentage of records (area of the normal curve) that would be outside the tolerance.

\section{RESULTS}

\subsection{Study 1 - Repeatability of milk recording and loss of precision due to the recording method (A4 vs. AT)}

Descriptive statistics of results for milk yield, fat, protein and lactose content from study 1 are presented in Table I. The data refers to a small sub sample (332 cows from 14 farms) of the Slovenian dairy cow population, however representative of the population (compared to data in Tab. II). According to the results in Table I, minimal differences in values were observed either between two consecutive days, two milkings or two different recording methods. Better repeatability (lower $\mathrm{s}_{\mathrm{r}}$ ) of daily milk yield was observed in case of morning than evening milking (Tab. III). The comparison of results obtained by the A4 or AT method shows better repeatability (lower $\mathrm{s}_{\mathrm{r}}$ ) for A4 compared to the AT recording method $\left(\mathrm{s}_{\mathrm{r}}\right.$ of $1.2 \mathrm{~kg}$ vs. $1.5-1.9 \mathrm{~kg}$, respectively), indicating a loss of precision in milk yield records due to the passage to the AT recording scheme. Consequently, we can expect daily milk yield to differ between two consecutive days up to about $3.4 \mathrm{~kg}$ in case of A4 method 
Table II. Descriptive statistics (means \pm standard deviations) for milk yield and composition for the data of the reproducibility study.

\begin{tabular}{lccccc}
\hline & $\mathrm{n}$ & Milk (kg) & Fat (\%) & Protein (\%) & Lactose (\%) \\
\hline AM milking & & & & & \\
Regular control (day 1) & 45029 & $9.0 \pm 3.6$ & $4.18 \pm 0.81$ & $3.40 \pm 0.39$ & $4.59 \pm 0.25$ \\
Supervision control (day 2) & 45029 & $9.0 \pm 3.6$ & $4.17 \pm 0.79$ & $3.40 \pm 0.39$ & $4.59 \pm 0.25$ \\
PM milking & & & & & \\
Regular control (day 1) & 12610 & $8.8 \pm 3.6$ & $4.23 \pm 0.79$ & $3.42 \pm 0.38$ & $4.60 \pm 0.26$ \\
Supervision control (day 2) & 12610 & $8.9 \pm 3.6$ & $4.19 \pm 0.77$ & $3.41 \pm 0.38$ & $4.59 \pm 0.26$ \\
Daily results & & & & & \\
${ }^{1}$ Regular control (day 1) & 57639 & $18.0 \pm 7.0$ & $4.16 \pm 0.64$ & $3.38 \pm 0.38$ & $4.59 \pm 0.25$ \\
${ }^{1}$ Supervision control (day 2) & 57639 & $17.9 \pm 6.9$ & $4.16 \pm 0.63$ & $3.38 \pm 0.37$ & $4.59 \pm 0.25$ \\
${ }^{2}$ Supervision control (day 2) & 57639 & $17.8 \pm 7.0$ & $4.19 \pm 0.70$ & $3.41 \pm 0.38$ & $4.59 \pm 0.25$ \\
\hline
\end{tabular}

AM: morning.

PM: evening.

${ }^{1}$ Daily results calculated according to the AT method.

${ }^{2}$ Daily results calculated according to the A4 method.

AT: monthly alternating recording scheme based on one daily milking adjusted for interval between milkings and time of milking.

A4: monthly recording scheme based on two daily milkings.

Table III. Repeatability (within operator) standard deviation $\left(\mathrm{s}_{\mathrm{r}}\right)$ and repeatability limit $(\mathrm{r})$ for milk yield and composition.

\begin{tabular}{lccccccccc}
\hline & \multicolumn{2}{c}{ Milk $(\mathrm{kg})$} & \multicolumn{2}{c}{ Fat $(\%)$} & \multicolumn{2}{c}{ Protein (\%) } & \multicolumn{2}{c}{ Lactose (\%) } \\
\hline $\mathrm{n}=332$ & $\mathrm{~S}_{\mathrm{r}}$ & $\mathrm{r}$ & $\mathrm{S}_{\mathrm{r}}$ & $\mathrm{r}$ & $\mathrm{s}_{\mathrm{r}}$ & $\mathrm{r}$ & $\mathrm{s}_{\mathrm{r}}$ & $\mathrm{r}$ \\
\hline AM milking & 0.8 & 2.2 & 0.54 & 1.51 & 0.14 & 0.39 & 0.12 & 0.34 \\
PM milking & 1.0 & 2.8 & 0.58 & 1.62 & 0.10 & 0.28 & 0.10 & 0.28 \\
Daily results A4 & 1.2 & 3.4 & 0.39 & 1.09 & 0.09 & 0.25 & 0.07 & 0.20 \\
Daily results AT - AM milking & 1.5 & 4.2 & 0.42 & 1.18 & 0.14 & 0.39 & 0.12 & 0.34 \\
Daily results AT - PM milking & 1.9 & 5.3 & 0.46 & 1.29 & 0.10 & 0.28 & 0.10 & 0.28 \\
\hline
\end{tabular}

AM: morning.

PM: evening.

AT: monthly alternating recording method based on one daily milking adjusted for the interval between milkings and time of milking.

A4: monthly recording method based on two daily milkings.

$\mathrm{s}_{\mathrm{r}}$ : repeatability standard deviation.

r: repeatability limit i.e. the value below which the absolute difference between two test results obtained under repeatability conditions may be expected to lie with a probability of $95 \%$ and hence $r=2.8 \times \mathrm{s}_{\mathrm{r}}$ [7].

and up to about $5.3 \mathrm{~kg}$ in case of AT method, just due to the random variation. Lower imprecision of AT compared to the A4 method was also observed for milk composition. Fat percentage was less repeatable (higher $s_{r}$ ) than protein or lactose percentage. Fat percentage calculated on a daily basis was more repeatable than fat percentage obtained for solely morning or evening milkings ( $\mathrm{s}_{\mathrm{r}}$ of $0.39-0.46 \%$ vs. 0.54 or $0.58 \%$, respectively). Regarding milk composition, we can normally expect the results to differ between two consecutive days up to about $1.3 \%, 0.4 \%$ and $0.3 \%$ 
Table IV. Reproducibility standard deviation $\left(\mathrm{s}_{\mathrm{R}}\right)$ and reproducibility limit $(\mathrm{R})$ for milk yield and composition.

\begin{tabular}{lccccccccc}
\hline & & \multicolumn{2}{c}{ Milk $(\mathrm{kg})$} & \multicolumn{2}{c}{ Fat $(\%)$} & \multicolumn{2}{c}{ Protein $(\%)$} & \multicolumn{2}{c}{ Lactose $(\%)$} \\
\hline & $\mathrm{n}$ & $\mathrm{S}_{\mathrm{R}}$ & $\mathrm{R}$ & $\mathrm{S}_{\mathrm{R}}$ & $\mathrm{R}$ & $\mathrm{S}_{\mathrm{R}}$ & $\mathrm{R}$ & $\mathrm{S}_{\mathrm{R}}$ & $\mathrm{R}$ \\
\hline AM milking & 45029 & 0.9 & 2.5 & 0.52 & 1.46 & 0.11 & 0.31 & 0.09 & 0.25 \\
PM milking & 12610 & 0.9 & 2.5 & 0.51 & 1.43 & 0.11 & 0.31 & 0.09 & 0.25 \\
${ }^{1}$ Daily results & 57639 & 1.7 & 4.8 & 0.40 & 1.12 & 0.11 & 0.31 & 0.09 & 0.25 \\
${ }^{2}$ Daily results & 57639 & 1.7 & 4.8 & 0.42 & 1.18 & 0.10 & 0.28 & 0.08 & 0.22 \\
\hline
\end{tabular}

AM: morning.

PM: evening.

$\mathrm{S}_{\mathrm{R}}$ : reproducibility standard deviation.

R: reproducibility limit i.e. the value below which the absolute difference between two test results obtained under reproducibility conditions may be expected to lie with a probability of $95 \%$ and hence $\mathrm{R}=$ $2.8 \times \mathrm{S}_{\mathrm{R}}[7]$.

${ }^{1}$ Daily results calculated according to the AT method in case of regular and supervision control.

${ }^{2}$ Daily results calculated according to the AT method in case of regular control and according to the A4 method in case of supervision control.

AT: monthly alternating recording scheme based on one daily milking adjusted for the interval between milkings and time of milking.

A4: monthly recording scheme based on two daily milkings.

for fat, protein and lactose percentage, just due to random variation.

\subsection{Study 2 - Reproducibility of milk recording and importance of factors related to the operator, herd or random variation. Reproducibility of milk yield recording in relation to herd size and cow productivity}

Table II comprises descriptive statistics for milk yield and composition of the extensive set of records from the Slovenian central milk recording data base obtained according to the AT method. These data reflect the average daily milk yield of Slovenian cows $(18 \mathrm{~kg})$ and milk composition (4.2\% of fat, $3.4 \%$ of proteins and $4.6 \%$ of lactose). On average, only minor differences in daily milk yield and composition could be noted between regular and supervision control or between morning and evening milking. A lower number of records reported for evening milking is due to the fact, that more supervision controls were performed in the morning. In case of AT recording scheme, the reproducibility standard deviation of daily milk recording results (Tab. IV) was comparable to repeatability standard deviation (Tab. III) estimates $\left(\mathrm{S}_{\mathrm{R}} 1.7 \mathrm{~kg}\right.$ vs. $\mathrm{s}_{\mathrm{r}} 1.5-1.9 \mathrm{~kg}$, respectively). On the contrary to the results of the first study, no differences in precision between morning and evening milking were detected. The estimate obtained for the reproducibility standard deviation $(1.7 \mathrm{~kg})$ indicates that we can normally expect daily milk yield between regular and supervision control to differ up to about $4.8 \mathrm{~kg}$. As for the milk composition, higher $\mathrm{S}_{\mathrm{R}}$ in case of fat than protein or lactose percentage confirmed that fat percentage is a less reproducible result than protein or lactose percentage. As in the first study, we could note better reproducibility (lower $\mathrm{s}_{\mathrm{R}}$ ) of fat percentage determined on the daily basis than on solely one milking. According to the results, we can normally expect daily results for milk composition to differ up to $1.2 \%$ for fat, and about $0.3 \%$ for 

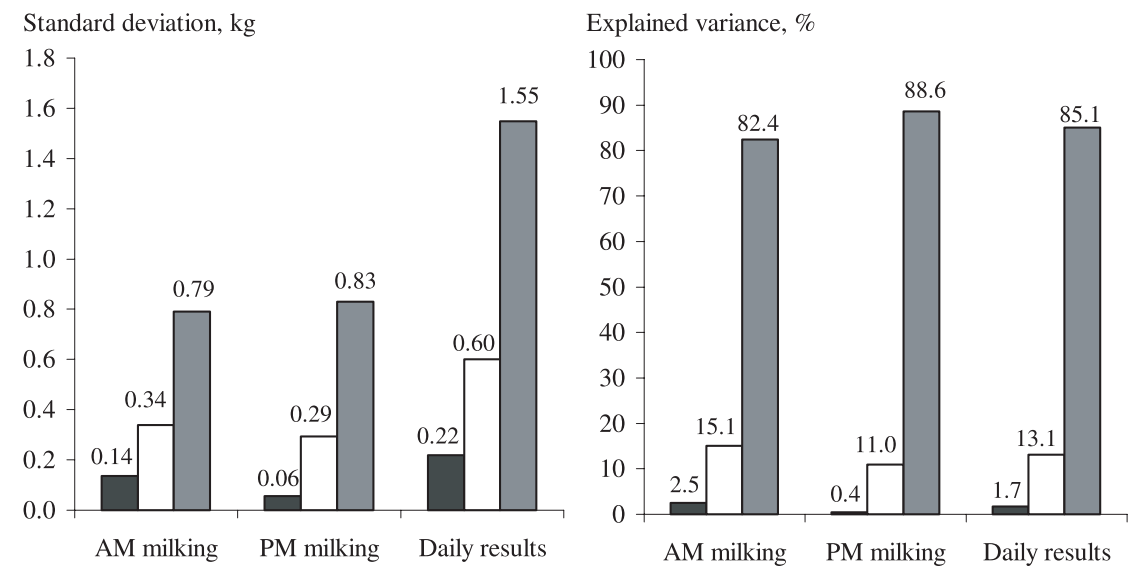

$\square$ Operator $\square$ Herd $\square$ Random variation

AM: morning

PM: evening

Daily results: according to AT method in case of regular and supervision control

Figure 1. Uncertainty of milk yield results ascribed to the operator, herd or random variation.

protein and lactose, respectively, which is comparable to the results obtained in the first study (within operator). Similar precision of milk recording results obtained in studies 1 and 2 indicates that the operator related factors are not critical for the uncertainty of milk recording. Indeed, the results for the uncertainty of milk yield that could be ascribed to the operator, herd or random variation (Fig. 1) support that idea. The factors related to the operator (reading, instrument, sampling, laboratory) accounted for a small part of variation (0.4$2.5 \%$ ) in milk yield whereas for fat, protein and lactose content, the operator's contribution was even lower (data not shown). The factors related to the herd seem to be far more important (11.0-15.1\% of variance), however, the main cause of variation $(82.4-88.6 \%)$ is random variation, an unexplained part related to the various biological and other uncontrolled, coincidental factors like heats, diseases, feeding. Considering herd size and production level of Slovenian milk production, it was in- teresting to evaluate uncertainty of daily milk yield recording in relation to herd size (Tab. V) and cow productivity (Tab. VI). Reproducibility of milk yield was associated with herd size and cow productivity. Higher uncertainty $\left(\mathrm{s}_{\mathrm{R}}\right.$ and $\left.\mathrm{RSD}_{\mathrm{R}}\right)$ of daily milk yield was observed for smaller herds with lower average productivity. Although increasing $S_{R}$ was associated with increasing productivity (Tab. VI), the uncertainty of milk yield results in relation to cow productivity $\left(\mathrm{RSD}_{\mathrm{R}}\right)$ was decreasing. Likewise, more than half of the records can be expected to over pass the acceptable tolerance $( \pm 10 \%)$ in case of low milk yields $(<10 \mathrm{~kg})$ whereas the percentage of failing records decreased with increased productivity.

\section{DISCUSSION}

Descriptive statistics obtained for the Slovenian population show the characteristic of Slovenian milk production, relatively 
Table V. Reproducibility standard deviation $\left(\mathrm{s}_{\mathrm{R}}\right)$ and reproducibility limit $(\mathrm{R})$ of milk yield according to herd size.

\begin{tabular}{lccccc}
\hline Herd size & \multirow{2}{*}{ No. of herds } & Herd average daily milk yield, $\mathrm{kg}$ & \multirow{2}{*}{$\mathrm{S}_{\mathrm{R}}$} & \multirow{2}{*}{$\mathrm{RSD}_{\mathrm{R}}$} & \multirow{2}{*}{$\mathrm{R}$} \\
\cline { 3 - 6 } (number of cows per herd) & Mean $\pm \mathrm{sd}$ & & & \\
\hline$<10$ & 1033 & $14.8 \pm 3.7$ & 0.9 & 6.1 & 2.5 \\
$10-20$ & 1474 & $16.5 \pm 3.4$ & 0.8 & 4.8 & 2.2 \\
$20-30$ & 554 & $18.3 \pm 3.6$ & 0.7 & 3.8 & 2.0 \\
$30-40$ & 183 & $19.3 \pm 3.7$ & 0.7 & 3.6 & 2.0 \\
$40-50$ & 93 & $20.5 \pm 3.5$ & 0.6 & 2.9 & 1.8 \\
$>50$ & 91 & $22.0 \pm 3.9$ & 0.6 & 2.7 & 1.8 \\
Total & 3428 & $16.7 \pm 4.0$ & 0.8 & 4.8 & 2.2 \\
\hline
\end{tabular}

$\mathrm{S}_{\mathrm{R}}$ : reproducibility standard deviation.

$\mathrm{RSD}_{\mathrm{R}}$ : relative reproducibility standard deviation.

$\mathrm{R}$ : reproducibility limit i.e. the value below which the absolute difference between two test results obtained under reproducibility conditions may be expected to lie with a probability of $95 \%$ and hence $\mathrm{R}=$ $2.8 \times \mathrm{s}_{\mathrm{R}}[7]$.

Table VI. Reproducibility standard deviation $\left(\mathrm{s}_{\mathrm{R}}\right)$ and reproducibility limit $(\mathrm{R})$ of milk yield according to cow productivity.

\begin{tabular}{lcccccc}
\hline Cow productivity (daily milk yield, $\mathrm{kg}$ ) & No. of cows & $\mathrm{S}_{\mathrm{R}}$ & $\mathrm{RSD}_{\mathrm{R}}$ & $\mathrm{R}$ & $\mathrm{AD}$ & Failing records (\%) \\
\hline$<10$ & 6269 & 1.3 & 17.3 & 3.5 & \pm 0.8 & 53.8 \\
$10-15$ & 15009 & 1.4 & 11.0 & 4.0 & \pm 1.3 & 35.3 \\
$15-20$ & 16353 & 1.6 & 9.2 & 4.4 & \pm 1.8 & 26.1 \\
$20-25$ & 11154 & 1.8 & 8.1 & 5.0 & \pm 2.3 & 20.1 \\
$25-30$ & 5506 & 2.0 & 7.3 & 5.6 & \pm 2.7 & 17.7 \\
$30-35$ & 2252 & 2.3 & 7.2 & 6.3 & \pm 3.2 & 16.4 \\
$>35$ & 1096 & 2.6 & 6.5 & 7.3 & \pm 3.9 & 13.4 \\
\hline
\end{tabular}

$\mathrm{s}_{\mathrm{R}}$ : reproducibility standard deviation.

$\mathrm{RSD}_{\mathrm{r}}$ : relative reproducibility standard deviation.

R: reproducibility limit i.e. the value below which the absolute difference between two test results obtained under reproducibility conditions may be expected to lie with a probability of $95 \%$ and hence $\mathrm{R}=$ $2.8 \times \mathrm{s}_{\mathrm{R}}[7]$.

AD: acceptable deviation $( \pm 10 \%)$.

Failing records (\%): percentage of records expected to exceed the acceptable deviation (AD).

small herds with lower productivity as compared to the countries with intensive milk production (Denmark, Finland, the Netherlands) and comparable to countries with similar natural conditions like Austria or Switzerland [5]. Minimal differences in milk yield observed between morning and evening milking in this study can be explained by the fact that the average milking interval was 12.1 hours (data not shown).
In the present study, general principles and definitions for estimating the precision (repeatability and reproducibility) of results were respected as proposed by the ISO 5725 standard [7]. Regarding the strict sense of definitions, the limitation relates to the repeatability as the interaction of the item (cow) with environmental conditions does not enable "constant operating conditions". Nevertheless, it indicates the 
random variation due to the uncontrolled factors. Both, repeatability and the reproducibility standard deviation can be related to what is known as "day to day variation", the difference being that repeatability standard deviation excludes the variation due to the factors associated with the operator taking the measurement. It is a common practice in different countries to apply certain tolerance $( \pm 5 \%$ to $\pm 10 \%$, [8]) for results obtained at regular and supervision control. In Slovenia, the tolerated difference between regular and supervision control during the A4 recording scheme was $\pm 10 \%$ (in relation to the supervision result). After the introduction of the AT recording method, we noted an increased frequency of controls outside the tolerance, which motivated this study. Lower repeatability of milk recording results in case of AT compared to the A4 recording scheme noted in our trial, indicates that introduction of the AT method, as a substitute for the A4 testing scheme, reduced the precision of daily milk recording results and explains the increased frequency of disparity in controls. Trappmann et al. [21], in conclusion to their study comparing the A4 and AT methods, signalled the existence of over or under estimation of daily results, but very high accuracy of estimation for the overall lactation. The loss of precision in daily milk recording results in the AT compared to the A4 method was also reported in a recent French study by Leclerc and Delacroix [10]; the degree of loss is difficult to compare, as they evaluated the loss of precision differently (as $1-\mathrm{R}^{2}$ ). According to them, the loss of precision was the most problematic for fat percentage, followed by daily milk yield. Simplification of recording presents considerable cost reduction but leads to a loss of precision, and its relative importance depends on further use of the results. The precision of daily milk recording is not so critical for the estimation of lactation yield (used for genetic evaluation), as it is com- pensated for by the sufficient number of controls. On the other hand, knowing the precision of daily milk recording results is of utmost importance, if the results are used for decisions regarding supervision or feeding management. Namely, we estimate that more than $75 \%$ of farmers in Slovenia do not dispose of the information on daily milk yield. Many of them use information obtained at monthly control for balancing concentrate supplement. Using results with lower precision (e.g. AT compared to A4 method) reduces not only the appropriate use of concentrates but increases the probability of problems in the herd. For example, in highly productive cows ( $>35 \mathrm{~kg}$ milk) we can expect $5 \%$ of records with error above $7.3 \mathrm{~kg}$ thus misestimating daily concentrate supplement for app. $3.5 \mathrm{~kg}$ which would lead to metabolic disorders. About a hundred years ago, when milk control was introduced for the first time in Slovenian herds, the experts were aware of the importance of precision in milk recording; at that time a regional milk supervisor Rado Legvart wrote in an old Slovenian booklet [13]: "Milk has to be weighed regularly every month; on two equally separated days and at each milking. Obtained daily quantities should be summed and divided by two. Thus the average daily milk yield of each month is evaluated."

Comparable precision of results obtained in study 1 (repeatability) and study 2 (reproducibility) indicates that the importance of the factors related to the operator (reading, instrument, sampling, laboratory) are not critical for the overall uncertainty of milk recording. This was further substantiated for milk yield by additional analysis which demonstrated that herd related factors were more influential and that the main part of the uncertainty is caused by random variation due to the biological variation and other uncontrolled factors. Our speculation that the regular control might be more biased was not confirmed as practically the same results were found for 
regular and supervision control (Tab. II). Nevertheless, the results show, that two randomly chosen operators could bring about $0.6 \mathrm{~kg}$ of difference in daily milk yield, which in a particular case could be important. For instance, the fact that operators do not rotate but service the same herds can represent a systematic error.

Comparison of our results to the literature data $[4,16,18-20]$ shows slightly higher "day to day variation" of Slovenian milk recording results. This observation might be explained by the structure and productivity of Slovenian dairy production. Namely, the uncertainty of milk yield recording in relation to herd size and cow productivity demonstrates that more uncertainty in daily milk recording can be expected in smaller herds with lower productivity, which is characteristic of the Slovenian dairy milk production. Higher percentage of records that could be expected to fail the tolerance limit $( \pm 10 \%)$ was associated with lower milk yields, which is an important result for breeds or herds with lower productivity or in case of sheep or goats, where we deal with lower milk yields and often simplified recording schemes. These results imply that rules of supervision should be adapted to the population under control.

\section{CONCLUSIONS}

Uncertainty of results addressed as repeatability and reproducibility was determined for Slovenian milk recording data. The difference between results on two consecutive days that can normally be expected in case of AT method was estimated to be about $5 \mathrm{~kg}$ for milk yield, $1.2 \%$ for fat and about $0.3 \%$ for protein or lactose. Similar values were obtained for repeatability and reproducibility of milk recording results. The major part of uncertainty was random variation i.e. various biological and other uncontrolled factors, while the "imprecision" due to the operator performing the control was very small. Lower repeatability of milk recording results was noted for the AT than A4 milk recording method, indicating loss of precision. Higher uncertainty of milk yield recording was associated with small herds and lower productivity, indicating that the rules for supervision should be adapted to the population under control.

\section{ACKNOWLEDGEMENTS}

The authors would like to express their very special thanks to the personnel of the Slovenian milk recording service attached to the Chamber of Agriculture and Forestry of Slovenia for their help in data collecting. The suggestions and comments of Dr. Eli V. Olsen (Danish Meat Research Institute) and anonymous reviewers are also greatly acknowledged.

\section{REFERENCES}

[1] Atwal A.S., Erfle J.D., Day-to-day variation in fat percent of cow's milk, Can. J. Anim. Sci. 70 (1990) 731-734.

[2] Everett R.W., Carter H.W., Burke J.D., Evaluation of the dairy herd improvement association recording system, J. Dairy Sci. 51 (1968) 153-162.

[3] Everett R.W., Waddell L.D., Sources of variation affecting the difference between morning and evening daily milk production, J. Dairy Sci. 53 (1970) 1424-1428.

[4] Friggens N.C., Rasmussen M.D., Milk quality assessment in automatic milking systems: accounting for the effect of variable intervals between milkings on milk composition, Livest. Prod. Sci. 73 (2001) 45-54.

[5] ICAR International Committee for Animal Recording, Available: http://www. icar.org/yearly_enquiry.htm [15.01.2006].

[6] ICAR International agreement of recording practises, Tunisia 2005, Available: http:// www.icar.org/docs/Rules\%20and\%20regulations/Guidelines/Guidelines_2005_final_low _resolution.pdf [30.05.2006]. 
[7] ISO 5725, Accuracy (trueness and precision) of measurement methods and results. International Organization for Standardization, CH-1211 Genève 20, Switzerland, 1994, 17 p.

[8] Klopčič M., Primerjava rezultatov kontrole in nadkontrole mlečnosti krav [The comparison of milk recording and milk supervision results in dairy cows]. Graduation thesis, Biotechnical faculty, Zootechnical department, Ljubljana, 1999.

[9] Klopčič M., Malovrh Š., Gorjanc G., Kovač M., Osterc J., Prediction of daily milk fat and protein content using alternating (AT) recording scheme, Czech J. Anim. Sci. 48 (2003) 449-458.

[10] Leclerc H., Delacroix J., Méthodes d'enregistrement des Performances du Contrôle Laitier Bovins. Comparaison des Méthodes Z4 et T4 avec la Méthode de Référence et les Performances Réelles, Institut de l'Élevage, 2004, Available: http://www.inst-elevage.asso.fr/ html1/article.php3?id_article $=5477$ \&origine $=49$ [18.11.2005].

[11] Lee A., Correlation between adjacent test days for fat percent, fat yield and milk yield, Can. J. Anim. Sci. 68 (1988) 295-298.

[12] Lee A.J., Wardrop J., Predicting daily milk yield, fat percent, and protein percent from morning or afternoon tests, J. Dairy Sci. 67 (1984) 351-360.

[13] Legvart R., Govedoreja (=Cattle breeding), published by the author, Ljubljana, 1910.
[14] McDaniel B.T., Accuracy of sampling procedures for estimating lactation yields: a review, J. Dairy Sci. 52 (1969) 1742-1761.

[15] Olsen E.V., Čandek-Potokar M., Oksama M., Kien S., Lisiak D., Busk H., On-line measurements in pig carcass classification. The repeatability and the variation due to the operator and copy of instrument, Meat Sci. (2006) in press.

[16] Rook A.J., Fisher W.J., Sutton J.D., Sources of variation in yields and concentrations of milk solids in dairy cows, Anim. Prod. 54 (1992) 169-173.

[17] SAS, The SAS version 8.2, SAS Inst. Inc., Cary, NC, USA, 2002.

[18] Svennersten-Sjaunja K., Larsson U., Bertilsson J., Sjaunja L.-O., The relative day-to-day variation in milk yield and composition for cows milked two or three times daily, in: 56th Annual Meeting of the European Association for Animal Production, Uppsala, Sweden, 2005, p. 382.

[19] Svennersten-Sjaunja K., Sjaunja L.-O., Bertilsson J., Wiktorsson H., Use of regular milking records versus daily records for nutrition and other kinds of management, Livest. Prod. Sci. 48 (1997) 167-174.

[20] Syrstad O., Day-to-day variation in milk yield, fat content and protein content, Livest. Prod. Sci. 4 (1977) 141-151.

[21] Trappmann Von W., Schwaer P., Pauw R., Tholen E., Alternate testing procedures as alternative for official milk recording, Zuchtungskunde 70 (1998) 85-95. 